\title{
INDIAN DECENTRINGS OF MACBETH: POSTMODERN CREATIVITY IN FILMIC ADAPTATIONS BY VISHAL BHARDWAJ AND JAYARAJ
}

\author{
Sritama MAITRA (D) ${ }^{1}$, Sangeeta MUKHERJEE (D) 2,* \\ 1, 2 Vellore Institute of Technology, School of Social Sciences and Languages, \\ Department of English, 632014 Vellore, India \\ ${ }^{1}$ Loyola Academy, Alwal, Hyderabad, 500010 India
}

Received 21 January 2020; accepted 30 June 2020

\begin{abstract}
The never-ending contemporaneity of William Shakespeare's Macbeth is established by the experimental adaptations of the play that have transcended time and space. The filmic adaptations, in particular, have recontextualized the original dramatic text in several innovative ways. This paper sets out to analyse from certain postmodern angles the creative and innovative adaptation of a classic literary text from a Scottish setting to two completely different Indian settings (geographically, culturally and politically) and also from 16th century Scotland, United Kingdom to two different time periods in India - Maqbool (director Vishal Bhardwaj, 2003) being a reimagination of Macbeth set in the 21st century underworld of Mumbai, India and Veeram (director Jayaraj, 2016) being an attempt to link the play with 13th century Kerala, India. The transmutations occur at multiple levels and this lends new interpretations to the text in two entirely different temporal and spatial contexts, though both of these adaptations are Indian.
\end{abstract}

Keywords: adaptation, drama, film, postmodernism, recontextualisation, William Shakespeare.

\section{Introduction}

The contemporaneity of Shakespeare in the 21st century is evinced perhaps most remarkably in the adaptations of his works in contemporary films. Filmic adaptations of Shakespeare's plays have cut across the borders of space and time, changing the face of adaptations as well as Shakespeare, the institution. Several poststructural and postmodernist experiments have been conducted on Shakespearean drama over the years, in the process of its translation into films and other media. Tom Stoppard's Rosencrantz and Guildenstern Are Dead ${ }^{1}$ (1990) is one of the best-known parodies of Shakespeare's plays where two minor characters from

\footnotetext{
$\overline{1}$ This film is based on Stoppard's play of the same name (first edition in 1966, see 2017).
}

${ }^{\star}$ Corresponding author. E-mail: sangeetamukherjee70@gmail.com

Copyright (c) 2020 The Author(s). Published by Vilnius Gediminas Technical University

This is an Open Access article distributed under the terms of the Creative Commons Attribution License (http://creativecommons. org/licenses/by/4.0/), which permits unrestricted use, distribution, and reproduction in any medium, provided the original author and source are credited. 
Hamlet become the protagonists (see Hibbard, 2008). A counternarrative to Romeo and Juliet (Shakespeare, 2018) was created by Ron West and Phillip Swann. Their play, The People vs Friar Laurence, the Man Who Killed Romeo and Juliet (West, 2010), is a musical comedy spoof set immediately after the death of Romeo and Juliet and told from the perspective of Friar Laurence. Gus Van Sant's My Own Private Idaho (1991) is a radical experiment, having combined loosely the plots of Henry IV of England, Part 1 and Part 2, and Henry V of England, to create a coming-of-age adventure drama with gay and bisexual protagonists. There is no dearth of examples such as the ones mentioned above in the re-envisioning of Shakespearean plays through various poststructural and postmodern devices.

This study aims to investigate the experimental re-imaginings of Shakespeare's Macbeth, namely Maqbool and Veeram by Indian filmmakers Bhardwaj, and Jayaraj respectively, and show how recontextualising Macbeth in two different Indian settings has turned out to be potent postmodern experimentation from the point of view of the changes that the text has undergone in the process, lending newer and fresher local meanings and perspectives to this timeless global tale as it rediscovers itself in the Indian subcontinent.

\section{Theoretical background}

"Decentering" as a poststructuralist term broadly refers to a way of understanding the world that negates the idea of a single way to interpret an event, or institution, or text. Poststructuralists recognized the inseparability of culture and meaning. Jacques Derrida and Roland Barthes were two crucial figures in the early post-structuralist movement. Derrida (2001) in his essay, "Structure, Sign, and Play in the Discourse of the Human Sciences", spoke of an event in intellectual life which he interpreted as an act of "decentering" the intellectual world which he referred to as a kind of "play". He pointed to the center of a structure which governs the structure by lending organization to it and argued that the center limits the possible play within the structure. "Play", therefore, is something that causes a rupture in the organization and coherence of the structure, thereby decentring the centre. The acknowledgement of this rupture points to the self-contradictoriness of language and makes it impossible to arrive at a meaning that is final and authoritative. In the poststructuralist and postmodern approach to textual analysis, decentring takes place with regard to the author's role, too. The author's intentionality is not considered to be of primary importance in the process of meaning-making. With the author losing precedence as the subject of critical enquiry, poststructuralists (and postmodernists) turn their attention to alternative sources of meaning like readers and cultural norms. Barthes (1977) in his essay "The Death of the Author" alluded to these concepts. With the "Death of the Author", Barthes also declared the "birth of the reader", as the source of meaning-making. He suggested that the reader must reject the authority of the author in order to perform their crucial task of (and also gain the pleasure of) playing with the text's plurality, its multiple layers, and meanings. These ideas are applicable to filmic adaptations of literary texts as well. The importance conferred on authorial intention has often led to film adaptations not being considered in their own right, leading almost always to debates on the film's fidelity to the original work. Very relevant here is Gordon E. Slethaug's reference to the approaches of some crucial postmodernist philosophers on the author's role (which is, again, 
very similar to the idea of Barthes) and relating the superior/inferior binary of the original work versus the translated work to the original literary text versus the film:

"His (Foucault's) tackling of a totalizing modernistic dialectic results in a hard look at historical assumptions, conceptions, and discursive practices and ways in which these can be explored, exposed, and possibly overturned. Among these, as Foucault notes in his essay "What Is an Author", is the privileged, "transcendental" position of the author [...] who, through various systems of attribution and valorization, was said to have established the unity, uniformity, and subjectivity of his/her text but whom Foucault claims is "dead", that is, no longer in control of the discourse, subjectivity, or circulation of the text. From this, it is a small leap to think about the problematic dialectic of a dominant, controlling written text and a subordinate film adaptation";

"Jean-François Lyotard also problematized the dominance of parent works in relation to daughter texts. He notes that an original often has been viewed as a master- or meta-narrative [...] with fullness, integrity, and indisputable "presence" - what another postmodern critic, Jacques Derrida, terms "totalization" [...], a third, Roland Barthes, calls a "work" with its normative cultural values of stable meaning, communication, and authorial intention [...], and a fourth, Mikhail Bakhtin, refers to as the "authoritative word" with transcendental meaning [...]. In this way, high value was given to those works that marked the reputed beginning of an artistic process/tradition, were deemed to be significant markers in the stages of its development, or were identified with a famous author" (Slethaug, 2014, pp. 20-21).

Thus, reimagining a literary text, through various reformulations and recontextualizations, becomes both a postmodern and poststructuralist creative device used in filmmaking that challenges the assumption that a film adaptation is a servile derivative of the original work. This is an act of decentering.

\subsection{Parody, pastiche, intertextuality}

Two devices that are most commonly seen in the adaptation of a literary text to a film are parody and pastiche which are potent tools of "decentring". Parody involves imitation of the matter or manner of the work, often for comic effect. In the process, the original is often deflated as a lowly subject matter is applied to the original work (Cuddon, 2013). However, parodying also entails reinterpreting a work in a way that Hutcheon and O'Flynn call "repetition with critical distance that allows ironic signaling of difference" (2006, p. 185). Parody often critiques the cultural aspects of the original text and engages in an enquiry with them with respect to the contemporary social scenario, thereby bringing fiction and reality on the same platform.

Pastiche, on the other hand, imitates while combining different genres, styles, and plots to create a completely new form. Like parody, pastiche is also intertextual in nature. Like parody again, pastiche is also used to make a commentary on social situations. Where pastiche differs from parody is in the fact that it does not aim to ridicule the text it draws from.

The origin of the term "intertextuality" is attributed to Julia Kristeva who used it to show how literary texts are interconnected (Moi, 1986, pp. 37-39). In interdisciplinary studies, this includes films, video games, advertisements, and even social media references. Intertextuality points to the interdependence of texts such that all texts that are newly created are connected 
to the ones that came before them and will bear a connection with the ones that come after them because texts cannot be produced in isolation and the materials for the creation of new literary texts must be obtained from the ones existing already. Every work spills over from the outlines of the book to become a part of a boundless network of literary and cultural connections and associations. The terms discussed before, namely parody and pastiche, are also devices of intertextuality. Intertextuality is an inseparable part of filmic adaptations since the filmic text is a reformulation of the text which it draws from. This invariably results in several new layers of meaning being created.

It may be mentioned here that postmodern and postructuralist devices have been selected with an awareness of the fact that the relevance of postmodernism is being questioned in these times and several defenses to it in the current times have also been convincingly presented. To quote Gibbons, "Postmodernism has taken various guises and, accordingly, there is no absolute consensus on what constituted it in the first place" (2018). One might add to this and say that there is no consensus on whether it is dead now despite the appearance of new terms that claim to have come to replace it, such as "post-postmodernism" "metamodernism"3, and "transmodernism"4 (although the primary argument of Gibbons in the essay seems to veer towards pronouncing death upon postmodernism). One might also add that postmodernism still thrives in various guises. To quote Pluckrose from her essay "No, Postmodernism is not Dead (and Other Misconceptions)":

"Nevertheless, there is still considerable genuine confusion and disingenuous obfuscation about how postmodernism is relevant to current problems in academia, social justice movements, and wider society, and this mostly comes from people who have studied it. It has become necessary to clarify what critics of postmodernism are and are not criticizing not only for the genuinely confused aficionados of some aspect of postmodernism but also for others who don't understand their objections because they have only considered it in a political/cultural sense" (2018).

In adaptation studies, postmodern techniques are still used in several ways, as this paper shall evince (both the films selected for this study having been made and released at the time when debates regarding the so-called demise of postmodernism were already rife and both having used several postmodern techniques). This is particularly because a huge number of adaptations still work on deconstructing and reconstructing or "decentering grand narratives".

\footnotetext{
2 Post-postmodernism stands for an "intensification and mutation within postmodernism" (Nealon, 2012).

3 The term occupies a medial space between modernism and postmodernism. The prefix " meta-' denotes derivation, resemblance, succession, and change" (Furlani, 2007, pp. 149-150). This implies that "metamodernism" stands for both a break from and a continuity with modernism. Turner in his article, "Metamodernism: a Brief Introduction" refers to metamodernism as "oscillating between sincerity and irony, deconstruction and construction, apathy and affect [...]" (2015).

4 Cole enumerates certain defining features of transmodernism, namely, adopting a different outlook towards life $v i s$ - - $v i$ s others, a rejection of Eurocentrism, imperialism and "totalising systhesis", "analogic reasoning", "analetic interaction" and respect towards religious, cultural, philosophical and moral traditions (2005).
} 


\section{Review of literature}

This review of literature focuses on the critical attention received by two adaptations of Shakespeare's Macbeth in Indian cinema: Maqbool and Veeram. A considerable amount of critical ink has been spilt on Bhardwaj's Maqbool, and even after fifteen years of its release, the film still receives critical attention as an attempt at the "bollywoodization" of Macbeth. Veeram, however, was released more recently, and there has not been much critical discussion on this ambitious project of director Jayaraj. Part of the reason behind the dearth of critical material on Veeram perhaps is that it is not a mainstream Hindi film but a regional film in Malayalam, and not quite suited to the tastes of the masses even in Malayali regional cinema. Predictably enough, therefore, this review of literature will weigh heavier in its discussion of Maqbool than that of Veeram.

Mark Thornton Burnett's Shakespeare and World Cinema relevantly notes that while Bhardwaj's Shakespearean adaptations move from the local to a global trajectory, Jayaraj's adaptations do the opposite (Thornton Burnett, 2013, p. 56). (This is actually true of both Maqbool and Veeram.) Goy-Blanquet (2014) in "Phantom of the Cinema: Macbeth's Ghosts in the Flesh" in the book Shakespeare on Screen: Macbeth, explores Bhardwaj's exoticisation of Shakespeare's Macbeth through changes in plot, characterization, the treatment of the supernatural and an unusual ending. In the same book, in an essay titled “A Barren Sceptre': Generation, Generations, and Destiny in Maqbool and Global Adaptations of Macbeth", Fleck (2014) analyses the departures that the film makes from the original text in order to supplant it to the Mumbai locale, while retaining the framework of the play in its plotline. Kumar's (2015) dissertation "Loose Translations: Postcolonial Literature and Shakespeare" focuses on the indigenisation of Lady Macbeth as seen in the character of Nimmi in Maqbool. Alexa Huang in "Shakespeare on Film in Asia" points out how Maqbool is "self-conscious about its local and international audiences" (2017, p. 230). Kapur and Pal (2017), in their essay "In the Morbid Interregnum: Vishal Bhardwaj's Realist Aesthetic and the Neoliberal Imaginary", investigate how Maqbool reveals a neoliberal India through a classic Shakespearean plot. In "Indigenising Shakespeare: A Study of Maqbool and Omkara", Sultana (2014) explores the parallels and contrasts between the dramatic text and the filmic text. Subarna Mondal, in her article "All the King's Men and All the King's Women: Reading Vishal Bhardwaj's Maqbool as a 'Creative Mistranslation' of Shakespeare's Macbeth" explores the treatment of communal politics in the film by viewing it as a representation of a part of Indian Muslim culture by a Hindu gaze. "Dissidence and Subversion within Power Structures: A Study of Maqbool and Macbeth" by Malhotra (2008) points out how the essence of the Shakespearean play remains untouched in its Bollywood adaptation, despite all the ways in which it is appropriated, because of the common thread of dissidence and subversion that runs through both the works. Wang's (2011) "Intermedial Representations in Asian Macbeth-s" attempts to decode the cultural meanings through landscape, body and the spectacle of power. Sen (2009) in "Indigenizing Macbeth: Vishal Bhardwaj's Maqbool" significantly points at the departures of Bhardwaj's adaptation: the complete shift in the relational dynamics in the film, the surprising way in which the sea in the film becomes a parallel of Birnam Wood of the play and the noncommittal ground that the film's ending takes, among other things. Orfall (2009), in his 
essay "From Ethnographic Impulses to Apocalyptic Endings: Bhardwaj's Maqbool and Kurosawa's Throne of Blood in Comparative Context", complicates Maqbool's use of Macbeth by forming a complex triangle of the texts through Bhardwaj's admission of the fact that he was inspired to make Maqbool after watching Akira Kurosawa's film.

As indicated before, there is precious little that has been written on Jayaraj's Veeram as an adaptation. Bhattacharyya's (2016) article “The Deathless Angel of English Literature, and the Living Legend" brings out the novelty of Jayaraj's project by explaining that the film is based on a ballad tradition of North Malabar, India which makes the work a transcreation and not merely a mechanical remake of the play in a South Indian language. Chintamani (2017), in the magazine Swarajya, attempts to answer the rather pertinent question: "Does the world need yet another cinematic retelling of the tragedy?". He answers the question in the affirmative which is established in the article by his references to other adaptations of Macbeth such as Orson Welles', Kurosawa's, Roman Polanski's and Bhardwaj's. Besides this rather scarce commentary available on Veeram, some newspaper articles have reported on the film, the reportage primarily based on the director's own vision and inspiration. The New Indian Express has quoted Jayaraj on the similarity he finds between the characters of Macbeth and Chandu (the protagonist of Veeram) and the fact that he has attempted to keep intact the authenticity of both Shakespeare's dramatic text and Jayaraj's filmic text while also giving free play to his creativity and employing "stylistic nuances" (Sudhish, 2016).

\section{Research gap}

The review of literature reveals that these two Indian filmic versions of Macbeth have not been considered together for analysis. It is intriguing that two completely different filmic adaptations of Macbeth (in time, space, treatment, and point of view) have arisen from the Indian soil, yet no comparative exploration of the two has been made yet. Also, an investigation into the postmodern techniques used in the Indianisation of Macbeth has not been carried out yet.

Research question 1: How do the two Indian adaptations of Macbeth reveal completely different cultural takes although they are both Indian adaptations of the 21 st century?

Research question 2: What kind of postmodern devices may be observed to emerge from the indeginisation of the two Indian Macbeths?

Research question 3: In which ways have the two Indian versions of Macbeth contributed to the continuing relevance of Macbeth adaptations?

\section{Postmodern instruments of filmic appropriation of Macbeth in the chosen film texts}

\subsection{Parody}

As stated before, the kind of parodying that is employed in the innovative and sometimes, radical film adaptations is "repetition with critical distance", to borrow a term from Hutcheon and O'Flynn. Both Maqbool and Veeram throw critical light on certain thematic aspects 
of the original text and underscore their relevance in the current social milieu. While both the films stay true to the basic themes (and universal emotions) of the corrupting nature of boundless ambition and the trusting leader's vulnerability to betrayal, the parodic elements of each help decenter and transcreate Shakespeare's Macbeth, creating an effective Hindi and a Malayali version respectively such that audiences who have had no acquaintance with the Shakespearean text would have no difficulty in seeing the films as "products" of a culture with which they are associated. Creative innovations in characterization offer the most telling ways of parodying in both the filmic texts. Each of the leading characters in Maqbool shows "critical distance" from the source text while being modelled on the Shakespearean ones they are inspired from. Miyan Maqbool as Macbeth is vulnerable, ambitious and has a basic nobility of character like Macbeth but his internal conflict is different, which in turn, makes his motivations differently inspired too, and brings him closer to the modern Indian man in his desires and his moral failings, thereby creating a morally weaker Macbeth but quite relatable as a 21st century Indian man. Those who have had exposure to the Shakespearean text is likely to infer that there is a Macbeth in all of us but our postmodern condition has rendered the Macbeths within us morally even weaker than Shakespeare's protagonist. Miyan Maqbool, like Macbeth, is morally conflicted by the concerns of honour, duty, ambition, love and what constitutes manly valour. But he is on the wrong side of conventional morality even before his principal conflict between ambition and duty can present itself to him, unlike his Shakespearean counterpart. This is because he is shown to be in an illicit relationship with the mistress of a man he considers to be a father figure and calls Abba Ji. This is doubly problematic. Miyan Maqbool owes Jahangir Khan (Abbaji) his career growth in the Mumbai underworld. The fact that chooses to cheat his mentor with his mistress shows his moral failing at one level. At the other level is the semi-incestuous angle that is unmistakable, Miyan Maqbool being in a relationship with his father figure's lover. His betrayal of Jahangir Khan (Abbaji) by murder and usurpation of his position comes later. Also, Miyan Maqbool seems much more motivated by his sense of loyalty and love for Nimmi (and the moral compulsion he must have felt as her lover to rescue her from a disgustingly exploitative relationship with Jahangir Khan (Abbaji) in committing the murder of his mentor than his dormant ambition to rise to the position of the boss (which was more pronounced in Macbeth). There is subtle parodying here. Similarly, Nimmi is reimagined as a woman who is scheming and plotting like Lady Macbeth but far more unscrupulous. This is because unlike Lady Macbeth, she has a personal stake in the murder she masterminds and the man whose murder she plans is her lover. Lady Macbeth goaded her husband to commit regicide because this was the only way in which she could see the rise of her husband to the position that she believed he deserved to be in, i.e., Kingship. However, Nimmi instigates Miyan Maqbool to murder her lover Jahangir Khan (Abbaji) because she is in a false relationship with the latter, evidently has no love for him, and is insecure about her position in the relationship and the privileges she gains from it because Jahangir Khan (Abbaji) has begun to take interest in a younger woman. This complicated web of relationships leading people to plot and execute murders is a very modern scenario which, like Miyan Maqbool's character, lends more credibility and relatability to her character in the 21st century setting but at the same time, takes away from her character the fiercely selfless love that Lady Macbeth had for her husband, which drove her to 
plan the king's murder only to see her husband rise in life. Because of the angles of betrayal, illegitimacy, and promiscuity, the relationship between Miyan Maqbool and Nimmi has none of the noble purity and loyalty of the relationship between Macbeth and Lady Macbeth. This is further muddled up later in the film when Nimmi informs Miyan Maqbool that she is pregnant but the latter cannot be sure initially whether the child is his or Abbajis. Again, there is not an iota of the unsuspecting goodness of Duncan's character in Jahangir Khan (Abbaji). He may be a venerated leader of his gang and a mentor to Miyan Maqbool but he is, after all, a mafia don, heading a "business" that is illegal and masterminding manslaughter regularly. Also, he is openly a debauch which makes him all the more reprehensible, morally. Consequently, the audience is expected to have mixed emotions at his death at the hands of Miyan Maqbool: while this is a morally repulsive man who dies, he perhaps did not deserve death at the hands of his protégé for whom he had been a benefactor figure. Conversely, in case of Duncan's death, there would definitely have been a sense of moral outrage at the treacherous murder of a just, kind and benign king. The most creative case of parodying perhaps happens in case of the witches. The three witches have been reduced to two corrupt policemen who are part-time astrologers and though they prevaricate like the witches and their prophecies do come true, they have none of the mystery of the witches but are rather lowly and ridiculous figures, albeit dangerous.

A similar parodying of the principal characters and their situations may be seen in Veeram. The fact that Veeram is a character who already existed in Kerala folklores and has been reimagined as a Macbeth prototype, further complicates the creative parodying of Macbeth in the film. Like Miyan Maqbool, Veeram has motivations other than just ambition in choosing the path of evil. There is jealousy and revengefulness resulting from him being denied the hand of his childhood sweetheart, Unniyarcha, in marriage. Like Maqbool again, a complicated love triangle has been formed in this story. While Unniyarcha is married to another man, Chandu remains attracted to her and she seems to return his passion, too. $\mathrm{He}$ allows himself to be seduced by her and even gives her hope that he would fight from Unniyarcha's side of the family in the fight to follow (the fight is a part of the rivalry between two clans for power and supremacy, and Chandu has just been made the lieutenant of one). Then there is Kuttimani, who is in love with Chandu and Chandu reciprocates her feelings as well, at least through his actions. He also promises to her that he would fight to defend her uncle, Aringodar, which is the exact opposite of what Unniyarcha was hoping from him (a hope he had encouraged). Kuttimani is revealed to be the equivalent of Lady Macbeth's character who instigates Chandu to betray and kill Aaroman, his mentor. Interestingly, she fans the flame of his ambition through the idea of revenge. She tells Chandu that he must betray his boss and mentor, Aaroman, because the latter did not allow him to marry the girl he loved, Unniyarcha. She seduces him and Chandu yields to her seduction too. The purpose of the seduction is two-fold. It enables Kuttimani not just to be intimate with Chandu but also to elicit his promise that he would betray his mentor Aaroman in the fight and help her uncle Aringodar win. This Macbeth figure is not loyal and honest in his romantic entanglements, a fault from which Shakespeare's Macbeth as well as Bhardwaj's Miyan Maqbool were free. Interestingly, although Chandu has been imagined as a 13th century Indian man, the romantic complications he allows himself to get embroiled in, are more relatable to the current day In- 
dian man. Since Kuttimani has not been designed to replicate the fierceness of Lady Macbeth and her unwavering perseverance to the cause of her husband's rise, Kuttimani is a different Lady Macbeth who uses Veeram/Macbeth to further her own family's ends. Unniyarcha, in fact, ends up being a more powerful female character in the film as rival to Kuttimani's love for Chandu and the woman who ultimately engineers Chandu's fall through her son. Unniyarcha's character has no equivalent in the Shakespearean play and is a part of the folklore which Jayaraj has ingeniously fused with the plot of Macbeth. Again, Aaroman has perhaps been deliberately made more flesh and blood in the film, more flawed and less grandiose as compared to the almost haloed presence of Duncan in Macbeth, in order to align the film well to its other source, the Vadakkan Pattukal or Northern Ballads of Kerala (NBK). Further, the three witches have been reduced to one sorceress who communicates through a virgin girl, again lending a local folklore element to create a substitute for the "weird sisters".

The love triangle and revenge motive are two tropes that have been used as innovative departures from the original text in both Maqbool and Veeram in order, perhaps, to lend more credibility to their protagonists' cold-blooded murder of their respective mentor figures. This makes both the films work effectively as creative parodies.

\subsection{Pastiche}

The combination of diverse elements like genres, styles, and plots can be observed in both Maqbool and Veeram in their decentering of the Shakespearean text. Maqbool, like many of its Western predecessors that are adaptations of Macbeth (such as Men of Respect (director William Reilly, 1990) and Joe Macbeth (director Ken Hughes, 1955)), brings in the mafia element to adapt the original tale of ambition to modern-day Mumbai underworld. Bhardwaj also incorporates the ingredients of a typical "Bollywood masala movie" by bringing in song and dance, romance (not just between Maqbool and Nimmi but also between Guddu and Sameera, Abbaji's daughter), the brief presence of a vamp and even an item number. There is a blend of influences even in terms of its sources of inspiration, as the film has been noted to have echoes of The Godfather (director Francis Ford Coppola, 1972) too, besides its primary source. Bhardwaj himself has admitted to being influenced by Kurosawa's Throne of Blood (Japanese: Kumonosu-jō, 1957) in his conception of the film's script (Pais, 2003). Besides, the film also partakes of the genre of a Bollywood musical with songs like "Rone do" and "Jhini mini jhini" having been used to propel the plot forward besides providing entertaining breaks in the storyline.

In the case of Veeram, the element of pastiche is more pronounced as the director himself has expressly stated his intention to combine a Kerala folk tale with the basic plot of Macbeth. The story of Chandu Chekavar taken from Vadakkan Pattukal ${ }^{5}$, a collection of Malayalam ballads of Medieval origin, and that of Macbeth from Shakespeare's Macbeth have been fused to create a unique amalgamation. Like Bhardwaj, Jayaraj has also admitted to being influenced by Kurosawa's Throne of Blood for this film (K, 2017) and therefore, has incorporated a warrior clan of Kerala, the Chekavars, drawing inspiration from the samurai element in

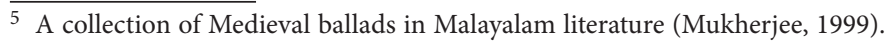


Throne of Blood. Kalaripayattu ${ }^{6}$, a traditional martial art form of Kerala, thus becomes the mode of conveying the struggle between the principal characters in the film. Again, as part of his project of the navarasa $a^{7}$ series of films, Veeram represents the rasa of "courage" or valour, bringing in another genre that the film may be said to partake of (Sreenivasan, 2016). This creative combination of genres in one film - classic Shakespearean tragedy, Medieval Malayalam folklore, traditional Kerala martial art setting, and the cinematisation of the veeram rasa of the navarasa series - contributes to forming an innovative pastiche. Krenn (2012) makes a comment on the postmodern film which is particularly relevant to this section and applies to both Maqbool and Veeram:

"[...] postmodern film is ever aware of the history of films, film genres and conventions, and of the fact of its producing rather than representing reality. Typically, earlier film styles or references to television programs are interwoven into postmodern film. Rock songs and other forms of popular culture reappear in recycled form. This is what Lyotard notes as eclecticism being 'the degree zero of contemporary general culture' [...]. However, the result is often referred to as 'pastiche'. The term 'pastiche' describes the imitation of a peculiar or unique style. In film, it is often used to pay homage to another film style or any other reference" (Krenn, 2012, pp. 28-29).

This comment effectively encapsulates the broad interpretation of the term "pastiche" which both the films under consideration may be said to have used.

\subsection{Intertextuality}

The spilling over of the identity of a classic Shakespearean tragedy into a different culture through a film adaptation of the text is a classic modern-day example of how a text lives through intertextuality. Adaptations constantly challenge the primary/secondary binary of book versus film adaptation because of the uncertain nature of their consumers. Many audiences of Maqbool and Veeram may not have known Macbeth and may have liked or disliked the films regardless. This clearly confers an identity to the film text independent of their source text. Yet the fact that the makers of these films expressly admit to having transcreated Macbeth in the films, the borrowed identity is equally a reality. This fragmented, postmodern identity is part of the politics of adaptation which effectively decenters the Shakespearean play, breathing new cultural interpretations to it. Both Bhardwaj and Jayaraj are self-confessed fans of Shakespeare and looking into the Shakespearean canon to find material for their films is a natural consequence of this inspiration. In an interview in Deccan Herald, Jayaraj says, "Shakespeare is an epitome of universality and I have always been keen on expressing his works on the big screen" (Narayanan, 2016). As for Bhardwaj, he too admits to having fallen in love with Shakespeare, albeit "accidentally", and also confesses that he realised the immensity of the adaptation he had chosen only when it was premiered at the Toronto International Film Festival in 2003, where he perceived the magnitude of Shakespeare's influence on world cinema (News18, 2018). However, both of these Indian versions of Macbeth, despite their

\footnotetext{
6 A martial arts form indigenous to Kerala, kalaripayattu drew inspiration from the raw energy and strength of powerful animals like lions, tigers, elephants and snakes.

7 The nine emotions mentioned by Bharata Muni in Natya Shastra, which is an attempt at categorising human emotions in different situations into nine concrete types (Pais, 2003).
} 
debt to the Shakespearean plot, are replete with several cultural shifts that the films undergo through each director's vision, making them in the process a part of the intertextual web of references. As indicated earlier, both Maqbool and Veeram have been influenced by Kurosawa's Throne of Blood. This affords a very interesting insight into intertextuality as it enables us to view two culturally dissimilar Indian Macbeths through the lens of a Japanese Macbeth, all of which ultimately hark back to an English Macbeth of the 16th century (which in turn has borrowed from Holinshed's Chronicles (first edition in 1577, see Hosley, 1968) and James VI's Daemonology (first edition in 1597, see King James I, 2016), among others). Maqbool, on the other hand, is not just a reworking of Shakespeare's text but also a nod to several other gangster films, especially The Godfather, as has been noted by several critics, among whom the observations of Jess-Cooke (2006) are particularly pertinent from the intertextual perspective. Jess-Cooke connects Maqbool not just to Ford Coppola's The Godfather but also, by extended association, to other Indian films that have attempted to rework The Godfather such as Mani Ratnam's Nayakan (1987) and Feroze Khan's Dharmatma (1975) and even to Luc Besson's Léon: The Professional (1994). Fleck points out that adapting Macbeth in a local mafia setting has also been done in other Western films like Reilley's Men of Respect and Penny Woolcock's Macbeth on the Estate (1997) (Fleck, 2014). It is not difficult to trace intertextuality working its complex web and forming intricate connections all through this network of films and literature.

As for Veeram, it being ostensibly a fusion of Shakespeare's Macbeth and the Vadakkan Pattukal on Chandu Chekavar ${ }^{8}$, this film may be said to be more inherently intertextual. Interestingly, another Malayalam film on the story of Chandu Chekavar, Oru Vadakkan Veergatha (1989) directed by Hariharan, had been made before and was well known to Jayaraj. In an interview, he states that Veeram is his way of looking at history in its allusion to the folk tales of Chandu Chekavar (K, 2017). Added to that is the influence of Kurosava's Throne of Blood which the director readily acknowledges. Besides Kurosawa, Jayaraj is aware of other classic films based on Macbeth like Polanski's Macbeth and his conscious or subconscious influence received from them would be undeniable (Sreenivasan, 2016). Intertextuality, thus, becomes an indispensable tool for any analysis of Veeram as a film.

\section{Discussion}

The above analysis will show that it addresses the research questions posed before.

First, indigenization, appropriation, and localization of Macbeth in the Indian context is the primary point of similarity between the two adaptations under consideration. Both are also products of postmodern methods of innovative retelling. The differences in treatment lie in one being a North Indian perspective and the other a South Indian one, one partaking of the elements of a mainstream Bollywood film while the other belonging more to the realm of the Indian regional cinema (the film may have been dubbed in Hindi and English too but a story based on the NBK and showcasing the culture of the kallaripayattu is bound to have more of Malayali audiences as its target viewers), one being set in modern Indian

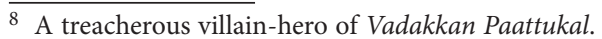


Mumbai and the other in 13th century Kerala, and the most obvious difference being that while one is decidedly urban in its setting and outlook, the other evokes a rustic South Indian atmosphere. Second, three potent postmodern devices, namely parody, pastiche, and intertextuality, are found to be operating in the films. Third, the fact that two culturally and cinematically different products have been created from Shakespeare's Macbeth in the 21st century in India allows one to conclude that not only does Macbeth continue to be relevant in the realm of adaptations but also that it holds the potential for generating many such culturally diverse cinematic products (India itself with all its cultural diversity affords many more such possibilities in filmic experimentations with Macbeth owing to the several different points of view that such a diversity allows for).

\section{Conclusions}

The decentering of Shakespeare's Macbeth may thus be observed to have been carried out in two completely different ways in two Indian adaptations of the play, creating two spatially and temporally altered versions of Macbeth in the film medium. When compared to their Western (say, Joe Macbeth) as well as eastern (say, Kurosawa's Throne of Blood) counterparts, these two Indian Macbeths are uniquely different Macbeths from them as well as from each other, in characterization, setting, as well as point of view. It is interesting to note that both the re-envisionings of Macbeth, through the postmodern devices of adaptation, have not only used Shakespeare's cultural capital but have also generated cultural capital of their own. They are not mere additions to the rather long list of Macbeth adaptations but stand unique in their cultural difference, Maqbool in representing the eclectic culture of the Mumbai underworld (combining the urban Indian complexities of religion, politics, Bollywood, astrology etc.) and Veeram in reviving an ancient rural culture of Kerala that is retold through a modern interpretation of an old folk tale. This is the creation of new cinema, new Macbeth and a new interpretation of Shakespeare, not just through a cultural translation of his classic play but also by breathing new meanings into his dramatic vision, enlarging its scope in ways not hitherto imagined, and including him within the cultural framework of India. Re-imaginings like these serve to confer immortality to Shakespeare in innovative ways. They show that the germ of the plot of Macbeth would always have the potentiality to spawn newer yet relevant versions of the text that would creatively borrow from their source on the one hand, and on the other hand, would not fail to achieve significance even in different time zones and in different socio-political and religious-cultural scenarios, provided the spirit of innovation through experimentation prevails. Not only does this ensure the continuing relevance of classic Shakespearean plays like Macbeth but also that of the possibility of continuously rediscovering new points of intersection between cultures.

\section{References}

Barthes, R. (1977). The death of the author. In Image-music-text (pp. 142-148). Fontana Press.

Bhattacharyya, S. (2016). The deathless angel of English literature, and the living legend. Research Journal of English Language and Literature, 4(4), 898-915. 
Chintamani, G. (2017). Across generations and cultures, the tragedy of Macbeth remains favourite with the filmmakers. Swarajya. https://swarajyamag.com/magazine/across-generations-and-cultures-the-tragedy-of-macbeth-remains-favourite-with-the-filmmakers

Cole, M. (2005). Transmodernism, Marxism and social change: some implications for teacher education. Policy Futures in Education, 3(1), 90-105. https://doi.org/10.2304/pfie.2005.3.1.12

Cuddon, J. A. (2013). A dictionary of literary terms and literary theory. Wiley-Blackwell. https://doi.org/10.1002/9781118325988

Derrida, J. (2001). Structure, sign, and play in the discourse of the human sciences. In Writing and difference (pp. 351-370). Routledge Classics. https://doi.org/10.4324/9780203991787-14

Fleck, A. (2014). "A Barren Sceptre”: generation, generations, and destiny in Maqbool and global adaptations of Macbeth. In S. Hatchuel, N. Vienne-Guerrin, \& V. Bladen (Eds.), Shakespeare on screen: Macbeth (pp. 289-290). Pressses universitaires de Rouen et du Havre.

Furlani, A. (2007). Guy Davenport: Postmodernism and after. Northwestern University Press.

Gibbons, A. (2018). Postmodernism is dead. What comes next? TLS. https://www.the-tls.co.uk/articles/ postmodernism-dead-comes-next/

Goy-Blanquet, D. (2014). Phantom of the cinema: Macbeth's Ghosts in the Flesh. In S. Hatchuel, N. Vienne-Guerrin, \& V. Bladen (Eds.), Shakespeare on screen: Macbeth. Pressses universitaires de Rouen et du Havre, 3.4.37.

Hibbard, G. R. (Ed.). (2008). The Oxford Shakespeare: Hamlet. Series: Oxford's World Classics. S. Wells (General Ed.). Oxford University Press.

Hosley, R. (Ed.). (1968). Shakespeare's Holinshed: An Edition of Holinshed's chronicles (1587). Source of Shakespeare's history Plays: King Lear, Cymbeline and Macbeth. Putnam.

Huang, A. (2017). Shakespeare on film in Asia. In J. L. Levenson \& R. Ormsby (Eds.), The Shakespearean world (pp. 225-240). Series: The Routledge Worlds. Routledge. https://doi.org/10.4324/9781315778341-13

Hutcheon, L., \& O’Flynn, S. (2006). A theory of adaptation. Routledge. https://doi.org/10.4324/9780203957721

Jess-Cooke, C. (2006). Screening the McShakespeare in Post-Millenial Shakespeare Cinema. In M. Thornton Burnett \& R. Wray (Eds.), Screening Shakespeare in the Twenty-First Century (pp. 163184). Edinburgh University Press.

K, P. (2017). Veeram not an interpretation justifying Chandu, but a close brush with history: Jayaraj. On Manorama. https://english.manoramaonline.com/entertainment/interview/jayaraj-on-veeram-kunal-kapoor-chandu-malayalam-movie.html

Kapur, J., \& Pal, S. (2017). In the Morbid Interregnum: Vishal Bhardwaj's realist aesthetic and the neoliberal imaginary. In A. Igbal Viswamohan \& V. M. John (Eds.), Behind the scenes: contemporary Bollywood directors and their cinema (pp. 131-159). SAGE.

King James I. (2016). Daemonologie in form of a dialogue divided into three books. CreateSpace Independent Publishing Platform.

Krenn, S. (2012). Postmodern and oriental elements in Moulin Rouge! Film Analysis. Series: Bachelorarbeit. Bachelor + Master Publishing/Dilomica Verlag GmbH.

Kumar, R. (2015). Loose translations: postcolonial literature and Shakespeare [unpublished Doctoral Thesis]. Emory University, Atlanta, Georgia, United States.

Malhotra, Sh. (2008). Dissidence and subversion within power structures: a study of Maqbool and Macbeth. Creative Forum, 21(1-2). https://www.questia.com/library/journal/1G1-258600231/dissidence-and-subversion-within-power-structures

Moi, T. (Ed.). (1986). The Kristeva reader. Columbia University Press. 
Mondal, S. (2017). All the King's men and all the King's women: Reading Vishal Bhardwaj's Maqbool as a 'Creative Mistranslation' of Shakespeare's Macbeth. Palgrave Communications. https://www.nature. com/articles/palcomms20172.pdf

Mukherjee, S. (1999). A dictionary of Indian literature. Vol. One: Beginnigs - 1850. Orient Longman Limited.

Narayanan, J. (2016). Making an international film is a challenge. Deccan Herald. https://www.deccanherald.com/content/568144/making-international-film-challenge.html

Nealon, J. T. (2012). Post-postmodernism, or, the cultural logic of just-in-time capitalism. Stanford University Press. https://doi.org/10.1515/9780804783217

News18. (2018). From Maqbool to Haider, Vishal Bhardwaj's "Accidental” romance with Shakespeare. news18. https://www.news18.com/news/movies/from-maqbool-to-haider-vishal-bhardwaj-opensup-on-his-accidental-romance-with-shakespeare-1756785.html

Orfall, B. (2009). From ethnographic impulses to apocalyptic endings: Bhardwaj's Maqbool and Kurosawa's Throne of Blood in comparative context. Borrowers and Lenders: The Journal of Shakespeare and Appropriation, 4(2). http://www.borrowers.uga.edu/1408/show

Pais, A. J. (2003). Maqbool is not meant for Shakespearean scholars. Rediff India Abroad. https://www. rediff.com/movies/2003/nov/06vishal.htm

Pluckrose, H. (2018). No, postmodernism is not dead (and other misconceptions). Areo. https://areomagazine.com/2018/02/07/no-postmodernism-is-not-dead-and-other-misconceptions/

Sen, S. (2009). Indigenizing Macbeth: Vishal Bhardwaj's Maqboo. Borrowers and Lenders: The Journal of Shakespeare and Appropriation, 4(2). http://www.borrowers.uga.edu/1419/show

Shakespeare, W. (2018). Romeo and Juliet. CreateSpace Independent Publishing Platform. https://doi.org/10.4324/9780429262715-13

Slethaug, G. E. (2014). Adaptation theory and criticism: postmodern literature and cinema in the USA. Bloomsbury Academic. https://doi.org/10.5040/9781501300110

Sreenivasan, D. (2016). Fusion of Chandu and Macbeth. Deccan Chronicle. https://www.deccanchronicle.com/entertainment/mollywood/290816/fusion-of-chandu-and-macbeth.html

Stoppard, T. (2017). Rosencrantz and Guildenstern are dead: A play. Grove Press.

Sudhish, N. (2016). Trans-Locating Macbeth to the Valiant Milieu of Vadkkan Pattu. The New Indian Express. https://www.newindianexpress.com/entertainment/malayalam/2016/sep/17/Trans-locating-Macbeth-to-the-valiant-milieu-of-vadkkan-pattu-1520511.html

Sultana, P. (2014). Indigenising Shakespeare: A Study of Maqbool and Omkara. Singularities, 1(2), 49-55.

Thornton Burnett, M. (2013). Shakespeare and world cinema. Cambridge University Press. https://doi.org/10.1017/CBO9780511760211

Turner, L. (2015). Metamodernism: A brief introduction. Notes on Metamodernism. http://www. metamodernism.com/2015/01/12/metamodernism-a-brief-introduction/

Wang, I.-Ch. (2011). Intermedial representations in Asian Macbeth-s. CLCWeb: Comparative Literature and Culture, 13(3). https://docs.lib.purdue.edu/cgi/viewcontent.cgi? article=1801\&context=clcweb

West, R. (2010). The People vs Friar Laurence, the Man Who Killed Romeo and Juliet. Samuel French, Inc. 


\title{
INDIŠKIEJI MAKBETO PERKEITIMAI: POSTMODERNUSIS KŪRYBIŠKUMAS VISHALO BHARDWAJAUS IR JAYARAJAUS FILMŲ ADAPTACIJOSE
}

\author{
Sritama MAITRA, Sangeeta MUKHERJEE \\ Santrauka
}

Williamo Shakespearre'o Makbeto nesenkantị šiuolaikiškumą steigia pjesės ekperimentinès adaptacijos, peržengiančios laiką ir erdvę. Filmų adaptacijose visų pirma keletu inovatyvių būdų buvo atnaujintas originalus dramos tekstas. Iš tam tikrų postmoderniojo požiūrio taškų straipsnyje siekiama išanalizuoti klasikinès literatūros teksto škotiškojo varianto bei dviejų visiškai skirtingų indiškųjų versijų (geografine, kultūrine ir politine prasmèmis) kūrybines ir inovatyvias adaptacijas, taip pat pasitelkiant XVI amžiaus Škotijos (Jungtinè Karalystè) du skirtingus laikotarpius apimančias indų interpretacijas - Makbulą (režisierius Vishalas Bhardwajus, 2003), kuris yra Makbeto varianto naujas pervaizdavimas XXI amžiaus Mumbajaus (Indija) pogrindinio pasaulio kontekste, ir Virama (režisierius Jayaraj, 2016), kuriame bandoma susieti pjesę su XIII amžiaus Kerala (Indija). Šie perkeitimai ịvyksta daugeliu lygmenų ir inspiruoja naujas teksto interpretacijas dviejuose visiškai skirtinguose laiko ir erdvès kontekstuose, nors abi šios adaptacijos ir yra indiškos.

Reikšminiai žodžiai: adaptacija, drama, filmas, postmodernizmas, rekontekstualizavimas, Williamas Shakespeare'as. 